\title{
PERANAN NOTARIS DALAM MEMBUAT PERJANJIAN KREDIT TANPA DIIKUTI DENGAN AKTA PEMBERIAN HAK TANGGUNGAN (APHT) MENURUT UNDANG-UNDANG NOMOR 4 TAHUN 1996 TENTANG HAK TANGGUNGAN
}

\author{
Oleh : \\ Iman Hidayat*
}

\begin{abstract}
ABSTRAK
Pembuatan perjanjian kredit dan pengakuan hutang, dibutuhkan peran Notaris dan Pejabat Pembuat Akta Tanah (PPAT). Notaris adalah seorang pejabat umum yang bertanggung jawab untuk membuat Surat Keterangan tertulis yang dimaksudkan sebagai bukti dari perbuatan-perbuatan hukum. Notaris memiliki kewenangan eksklusif untuk membuat akta-akta otentik. Dalam Pasal 10 ayat 2 Undang-Undang Nomor 4 Tahun 1996 tentang Hak Tanggungan yaitu Pemberian Hak Tanggungan dilakukan dengan pembuatan akta pemberian hak tanggungan oleh PPAT sesuai dengan peraturan perundang-undangan yang berlaku untuk berlakunya suatu pemberian hak tanggungan diatur dalam Pasal 13 ayat (1) Undang-Undang Nomor 4 Tahun 1996 tentang Hak Tanggungan yaitu pemberian hak tanggungan wajib didaftarkan pada kantor pertanahan. Dari kedua peraturan tersebut sudah merupakan suatu syarat mutlak bagi kreditur yang dalam hal ini adalah bank dalam memberikan kredit kepada debitur dengan jaminan hak tanggungan, maka harus dibuatkan Akta Pemberian Hak Tanggungan sebagai jaminan pelunasan utang debitur kepada kreditur.Namun perkembangannya dalam dunia perbankan terdapat bank yang memberikan kredit kepada debitur tidak diikuti dengan Akta Pemberian Hak Tanggungan sebagai jaminan pelunasan utangnya. Disini terjadi penyimpangan dalam proses pemberian kredit dari bank kepada nasabah yang mana seharusnya bank dalam pemberian kredit kepada nasabahnya harus diikuti dengan jaminan sebagai pelunasan terhadap kredit yang diberikan
\end{abstract}

Kata Kunci: Peranan Notaris, APHT, Perjanjian

\section{A. Latar Belakang}

Pembangunan merupakan terencana dan terarah yang mencakup aspek ekonomi, demokrafi, psikologi, hukum, intelektual maupun teknologi dalam kehidupan masyarakat. Salah satu bentuk pembangunan adalah pembangunan di bidang usaha perbankan.

Menurut Undang-Undang Nomor 10 Tahun 1998 tentang Perubahan UndangUndang Nomor 7 Tahun 1992 tentang Perbankan, bahwa bank adalah badan usaha yang menghimpun dana dari masyarakat dalam bentuk simpanan dan menyalurkan kepada masyarakat dalam bentuk kredit dan atau bentuk kredit lainnya dalam rangka meningkatkan taraf hidup rakyat.

\footnotetext{
* Pengajar Program Magister Ilmu Hukum Unbari.
} 
Perjanjian kredit adalah sarana pembangunan untuk mendapatkan kredit, penerima kredit terikat pada syarat-syarat tertentu dan merupakan suatu perjanjian yang dibuat kreditur dan debitur berdasarkan persetujuan atau kesepakatan kreditur dan debitur, sedangkan kreditur berkewajiban untuk memberikan uang atau kredit kepada debitur dan debitur berkewajiban untuk membayar pokok dan bunga, serta biaya-biaya lainnya sesuai dengan jangka waktu yang telah disepakati antara keduanya. Kreditur adalah orang atau badan hukum yang memberikan kredit kepada debitur. ${ }^{1}$

Debitur adalah orang atau badan hukum yang menerima kredit dari kreditur. Kredit menurut Undang-Undang Nomor 7 Tahun 1992 Pasal 1 angka 12, kredit yaitu penyediaan uang atau tagihan yang dipersamakan dengan itu, berdasarkan persetujuan atau kesepakatan pinjam-meminjam untuk melunasi utangnya dalam jangka waktu tertentu dengan pemberian bunga.

Kreditur memberikan kredit kepada debitur dan debitur berkewajiban untuk membayar pokok dan bunga, serta biaya-biaya lainnya. Bunga pinjaman adalah pendapatan yang diterima kreditur secara berkala atas penggunaan kredit oleh debitur, sesuai yang disepakati dalam kredit, serta biaya-biaya lain meliputi denda keterlambatan dalam pembayaran pokok dan bunga. ${ }^{2}$ Adapun jangka waktu kredit adalah masa berlakunya perjanjian kredit yang dibuat oleh para pihak.

Pembuatan perjanjian kredit dan pengakuan hutang, dibutuhkan peran Notaris dan Pejabat Pembuat Akta Tanah (PPAT). Notaris adalah seorang pejabat umum yang bertanggung jawab untuk membuat Surat Keterangan tertulis yang dimaksudkan sebagai bukti dari perbuatan-perbuatan hukum. Notaris memiliki kewenangan eksklusif untuk membuat akta-akta otentik.

Akta notaris sebagai alat bukti akan mempunyai pembuktian yang sempurna apabila seluruh ketentuan, prosedur dan tata cara pembuatan akta dipenuhi. Jika ada prosedur yang tidak dipenuhi dan dapat dibuktikan maka akta tersebut melalui proses pengadilan dapat dinyatakan sebagai akta di bawah tangan yang pembuktiannya diserahkan kepada hakim. Ketentuan dalam formulir tersebut kebanyakan menguntungkan pihak bank/kreditur dan cenderung merugikan pihak nasabah/debitur.

\footnotetext{
30.

${ }^{1}$ Mariam Darus Badrulzaman, Perjanjian Kredit Bank, Alumni, Cet. 1, Bandung, 1989, hal. hal. 1.

${ }^{2}$ H. Budi Untung, Kredit Perbankan Di Indonesia, Andi Untung, Cet. I, Yogyakarta, 1959,
} 
Perkembangan profesi notaris (termaksud PPAT) sangat terpengaruh oleh pertumbuhan ekonomi dan adanya masyarakat yang memberikan kebebasan sangat luas bagi individu untuk "menciptakan" sendiri hubungan-hubungan hukum. Lalu lintas hukum membutuhkan adanya tingkat kepastian tertentu, notaris menawarkan ini karena ia seorang fungsionaris yang mandiri, yang sekaligus memiliki kewajiban untuk menjaga terciptanya keseimbangan dalam setiap hubungan hukum. ${ }^{3}$

Dengan demikian, selain keharusan adanya perjanjian kredit sebagai perjanjian pokok, maka untuk kepentingan bank, dalam hal ini jaminan pengembalian kredit yang diberikan, benda jaminan atau agunan yang diserahkan oleh debiturnya, harus dilakukan pengikatan atau pembebanan hak tanggungan yang dibuat oleh Pejabat Pembuat Akta Tanah (PPAT).

Dalam Pasal 10 ayat 2 Undang-Undang Nomor 4 Tahun 1996 tentang Hak Tanggungan yaitu Pemberian Hak Tanggungan dilakukan dengan pembuatan akta pemberian hak tanggungan oleh PPAT sesuai dengan peraturan perundang-undangan yang berlaku untuk berlakunya suatu pemberian hak tanggungan diatur dalam Pasal 13 ayat (1) Undang-Undang Nomor 4 Tahun 1996 tentang Hak Tanggungan yaitu pemberian hak tanggungan wajib didaftarkan pada kantor pertanahan. Dari kedua peraturan tersebut sudah merupakan suatu syarat mutlak bagi kreditur yang dalam hal ini adalah bank dalam memberikan kredit kepada debitur dengan jaminan hak tanggungan, maka harus dibuatkan Akta Pemberian Hak Tanggungan sebagai jaminan pelunasan utang debitur kepada kreditur. ${ }^{4}$

Namun perkembangannya dalam dunia perbankan terdapat bank yang memberikan kredit kepada debitur tidak diikuti dengan Akta Pemberian Hak Tanggungan sebagai jaminan pelunasan utangnya. Disini terjadi penyimpangan dalam proses pemberian kredit dari bank kepada nasabah yang mana seharusnya bank dalam pemberian kredit kepada nasabahnya harus diikuti dengan jaminan sebagai pelunasan terhadap kredit yang diberikan.

\section{B. Rumusan Masalah}

${ }^{3}$ Tan Thong Kie, Studi Notaris, Serba-serbi Notaris, PT. Ichtiar Baru Van Hoeve, Cet. I, Jakarta, 1994, hal. 218.

${ }^{4}$ H. Salim, Perkembangan Hukum Jaminan di Indonesia, PT. Raja Grafindo Persada, Cet. I, Jakarta, 2004, hal. 161. 
Permasalahan pokok yang ingin dikemukakan sehubungan dengan masalah yang dibahas adalah :

1. Bagaimana status perjanjian kredit yang dibuat tanpa diikuti dengan Akta Pemberian Hak Tanggungan (APHT) menurut Undang-Undang Nomor 4 Tahun 1996 tentang Hak Tanggungan?

2. Bagaimana akibat hukum terhadap perjanjian kredit tanpa diikuti dengan Akta Pemberian Hak Tanggungan (APHT) dihadapan PPAT ?

\section{Metode Penelitian}

1. Tipe Penelitian

Mengacu pada perumusan masalah dan tujuan penelitian tersebut di atas, maka penelitian ini dilakukan dengan menggunakan penelitian hukum normatif. Penelitian hukum normatif mencakup penelitian terhadap asas-asas hukum, sistematika hukum, sinkronisasi hukum, dan sejarah hukum.

Penelitian normatif diambil sebagai pendekatan dalam penelitian ini karena yang menjadi perhatian utama adalah ketentuan perundang-undangan yang mengatur mengenai perbuatan pidana dan sanksi pidana penayangan siaran televisi yang dapat menyebabkan terjadinya kriminalitas di kalangan anak-anak.

2. Pendekatan yang Digunakan

Berdasarkan tipe penelitian normatif tersebut di atas, maka pendekatan yang digunakan dalam penelitian ini adalah pendekatan konseptual (conceptual approach), pendekatan perundang-undangan (normative approach) dan pendekatan sejarah (historical approach).

Terkait dengan pendekatan tersebut, dalam penelitian ini akan digambarkan tentang hal-hal yang berkaitan dengan perbuatan dan pertanggungjawaban pidana penyiaran.

Setelah bahan-bahan hukum tersebut terkumpul, maka dilakukan analisis dengan cara:

a. Menginterpretasikan semua peraturan perundang-undangan sesuai masalah yang dibahas.

b. Mengevaluasi peraturan perundang-undangan yang berhubungan dengan masalah yang diteliti.

c. Menilai bahan-bahan hukum yang berhubungan dengan masalah yang dibahas. 


\section{Status Perjanjian Kredit Tanpa Diikuti Akta Pemberian Hak Tanggungan Dihadapan PPAT Menurut Undang-Undang Nomor 4 Tahun 1996 Tentang Hak Tanggungan}

Status perjanjian kredit tanpa diikuti Akta Pemberian Hak Tanggungan (APHT) dihadapan PPAT menurut Undang-Undang Nomor 4 Tahun 1996 tentang Hak Tanggungan, menurut pendapat penulis perjanjian kredit tersebut adalah tetap sah secara hukum karena dalam Undang-Undang Nomor 4 Tahun 1996 tentang Hak Tanggungan tidak terdapat pengaturan yang menyebutkan akan batalnya suatu perjanjian kredit, jika dibuat tanpa diikuti dengan Akta Pemberian Hak Tanggungan (APHT).

Melihat dari bunyi Pasal 10 ayat 1 Undang-Undang Nomor 4 Tahun 1996 tentang Hak Tanggungan yang berbunyi "Pemberian Hak Tanggungan dengan janji untuk memberikan Hak Tanggungan sebagai jaminan pelunasan hutang tertentu, yang dituangkan di dalam dan merupakan bagian tak terpisahkan dari perjanjian utangpiutang yang bersangkutan atau perjanjian lainnya yang menimbulkan utang tersebut, maka menurut penulis ada atau tidak dibuatnya Akta Pemberian Hak Tanggungan dalam pemberian suatu kredit adalah hanya sebagai perjanjian tambahan yang mengikuti perjanjian pokok, terbukti bunyi pasal dalam undang-undang yang menyebutkan janji untuk memberikan Hak Tanggungan sebagai jaminan pelunasan utang tertentu, yang dituangkan di dalamnya dan merupakan bagian tak terpisahkan dari perjanjian utang piutang yang bersangkutan atau perjanjian lainnya yang menimbulkan utang tersebut.

Sedangkan dalam Undang-Undang Nomor 4 Tahun 1996 tidak terdapat pengaturan yang akan membatalkan perjanjian kredit yang dibuat tanpa diikuti dengan Akta Pemberian Hak Tanggungan (APHT), maka untuk menjawab pertanyaan status hukum perjanjian kredit tanpa diikuti Akta Pemberian Hak Tanggungan, kita harus melihat pada perjanjian kredit itu sendiri. Dimana untuk menentukan sah atau tidaknya suatu perjanjian ditentukan dengan Pasal 1320 KUHPerdata tentang syarat sah suatu perjanjian.

Mengenai syarat sahnya suatu perjanjian dapat ditemukan dalam Pasal 1320 KUHPerdata, yang menentukan bahwa untuk sahnya suatu perjanjian diperlukan 4 syarat yaitu :

1. Sepakat bagi mereka yang mengikat dirinya; 
2. Kecakapan untuk membuat suatu perikatan;

3. Suatu hal tertentu;

4. Suatu sebab yang halal.

Syarat pertama dan syarat kedua merupakan syarat subjektif yaitu mengenai orang yang mengadakan perjanjian, jika syarat subyektif ini tidak dipenuhi dalam suatu perjanjian maka salah satu pihak dapat meminta perjanjian tersebut dibatalkan, untuk membatalkan perjanjian tersebut maka salah satu pihak harus meminta perjanjian tersebut dibatalkan pada pihak lain.

Sedangkan untuk syarat ketiga dan syarat keempat merupakan syarat obyektif, jika kedua syarat itu tidak dipenuhi, maka perjanjian tersebut batal demi hukum, artinya dari sejak awal tidak pernah dilahirkan suatu perjanjian dan dengan sendirinya tidak terjadi perikatan diantara mereka dengan kata lain perjanjian tersebut dianggap tidak pernah ada.

1. Kata sepakat bagi mereka yang mengikatkan diri

Sepakat yang dimaksud adalah dari para pihak yang mengadakan perjanjian itu harus ada sepakat mengenai hal yang diperjanjikan, dengan demikian diisyaratkan adanya persetujuan mengenai isi perjanjian antara kedua belah pihak yang mengadakannya.

Pengertian sepakat atas persetujuan dimaksud, bahwa kedua subjek yang mengadakan itu harus sepakat, atau seia sekata mengenai hal-hal, maka pihak lain mengkehendakinya oleh pihak yang satu, maka pihak lain mengkehendaki hal yang sama timbal balik. Dalam hal kata sepakat itu tidak boleh yang cacat, sebab kalau perjanjian atau kesepakatan dapat pula minuta pembatalannya di pengadilan, yang dapat dikatakan cacat itu adalah seperti adanya unsur penipuan, paksaan dan kekhilafan.

2. Kesepakatan untuk membuat suatu perikatan

Setiap orang yang sudah dewasa dan sehat akalnya adalah cakap menurut hukum, orang tidak cakap membuat perjanjian disebut dalam Pasal 1330 KUHPerdata, yaitu :

a. Orang yang belum dewasa;

b. Orang yang taruh di bawah pengampunan.

3. Orang perempuan/isteri dalam hal telah ditetapkan oleh undang-undang dan semua orang kepada siapa undang-undang telah melarang membuat perjanjian tersebut. 
Dalam pengertian ini artinya prestasi ini harus diperinci sehingga dapat diketahui dengan jelas dari perjanjian tersebut, jadi hak dan kewajiban kedua belah pihak ini harus jelas sehingga apabila terjadi perselisihan, bisa ditentukan perincian serta maksud objek yang diperjanjikan.

4. Suatu sebab yang halal

Sebab dalam hal ini bukan diartikan sebagai sesuatu yang menimbulkan akibat yang dimaksudkan dengan yang halal. Namun isi dari perjanjian tersebut haruslah tidak bertentangan dengan undang-undang kesusilaan dan ketertiban umum. $^{5}$

Menurut analisis penulis dari teori syarat sahnya suatu perjanjian yang terdapat dalam Pasal 1320 KUHPerdata, maka perjanjian kredit walaupun tidak diikuti dengan Akta Pemberian Hak Tanggungan tidak membatalkan perjanjian kredit tersebut dan tetap sah secara hukum.

Namun ada pihak bank yang tidak mau mengambil resiko terhadap debitur yang mungkin melawan wanprestasi atau cidera janji sehingga pihak bank hanya mengikat jaminan dengan Surat Kuasa Membebankan Hak Tanggungan (SKMHT), maka berlakunya Surat Kuasa Membebankan Hak Tanggungan hanya 1 bulan yang sudah bersertifikat, sedangkan tiga bulan belum bersertifikat.

\section{Akibat Hukum Perjanjian Kredit Tanpa Diikuti Akt Pemberian Hak Tanggungan (APHT) Dihadapan Pejabat Pembuatan Akta Tanah}

Berdasarkan hasil analisis terdapat akibat hukum perjanjian kredit tanpa diikuti Akta Pemberian Hak Tanggungan (APHT) yang dibuat dihadapan Pejabat Pembuatan Tanah, menurut pendapat penulis akibat hukum terhadap perjanjian kredit tersebut adalah hasil pengambilalihan jaminan atau harta yang dimiliki debitur tidak cukup untuk pelunasan uang debitur tersebut, maka kreditur akan mengalami kerugian atas pemberian utang tersebut.

Menurut penulis, bank tidak memiliki jaminan terhadap kredit yang diberikan kepada debitur, namun pelunasan utang dari pada debitur, jika terjadi wanprestasi yaitu mengacu pada Pasal 1131 KUHPerdata, dimana diletakkanlah asas umum hak seorang kreditur terhadap debiturnya, dalam mana ditentukan bahwa segala kebendaan debitur, baik yang bergerak maupun tidak bergerak, baik yang sudah ada maupun yang baru

${ }^{5}$ Subekti, Hukum Perjanjian Kredit, PT. Intermasa, Cet. I, Jakarta, 1991, hal. 17. 
akan ada dikemudian hari, menjadi tanggungan untuk segala perikatannya, ini menunjukkan piutang kreditur meliputi seluruh harta debitur tanpa kecuali.

Sedangkan resiko yang mungkin timbul bagi debitur jika jaminan tanpa diikuti pembebanan hak tanggungan apabila terjadi suatu wanprestasi ialah pelunasan utang debitur dengan pengambil alihatan/penjualan jaminan tersebut tidak sesuai dengan utang debitur, maksudnya ialah nilai jaminan debitur yang menjadi tanggungan pelunasan utang debitur jauh lebih besar dibandingkan dengan nilai utang debitur.

Undang-Undang Republik Indonesia Nomor 14 Tahun 1967 untuk mengatur tentang pemberian kredit oleh bank, bahwa pada dasarnya setiap pemberian oleh bank selalu diikuti dengan jaminan kredit guna memperkecil resiko bank dalam menyalurkan kredit. Secara umum jaminan kredit dapat diartikan sebagai penyerahan kekayaan atau pernyataan kesanggupan seseorang untuk menanggung pembayaran kembali suatu hutang.

Kegunaan jaminan itu sendiri adalah :

1. Memberikan hak dan kekuasaan kepada bank untuk mendapatkan pelunasan dari hasil penjualan barang jaminan tersebut, apabila nasabah melakukan cidera janji yaitu tidak membayar utangnya pada waktu yang telah ditentukan dalam perjanjian.

2. Menjamin dalam nasabah berperan serta dalam transaksi untuk membiayai usahanya, sehingga kemungkinan untuk meninggalkan usahanya proyeknya dengan merugikan dirinya sendiri atau perusahaannya, dapat dicegah atau sekurangkurangnya kemungkinan untuk dapat berbuat demikian diperkecil terjadinya hal tersebut.

3. Memberi dorongan pada debitur untuk memenuhi perjanjian kredit khususnya mengenai pembayaran kembali sesuai dengan syarat-syarat yang telah disetujui agar debitur tidak kehilangan yang telah dijaminkan kepada bank.

Sehingga menurut penulis, bahwa seharusnya perjanjian kredit harus diikuti dengan Akta Pemberian Hak Tanggungan (APHT) yang dibuat dihadapan PPAT karena Hak Tanggungan memiliki unsur pokok yaitu :

1. Hak tanggungan adalah hak jaminan untuk pelunasan hutang;

2. Objek hak tanggungan adalah hak atas tanah sesuai Undang-Undang Pokok Agraria (UUPA); 
3. Hak tanggungan dapat dibebankan atas tanahnya (hak atas tanah) saja, tetapi dapat pula dibebankan berikut benda-benda lain yang merupakan satu kesatuan dengan tanah itu;

4. Hutang yang dijamin adalah hutang tertentu;

5. Memberikan kedudukan yang diutamakan kepada debitur tertentu terhadap kreditur-kreditur lain.

Dimana dapat dilihat bahwa adanya Hak Tanggungan atas perjanjian kredit, jika terjadi wanprestasi atau perjanjian kredit, maka adanya hak jaminan untuk pelunasan hutang tersebut dan kedudukan kreditur diutamakan kreditur lain, sehingga disini bank dapat meminimalkan resiko kerugian yang kemungkinan terjadi apabila debitur wanprestasi.

\section{E. Kesimpulan}

Dari keseluruhan yang telah dijabarkan oleh penulis, maka dapat ditarik kesimpulan sebagai berikut :

1. Status perjanjian kredit yang dibuat tanpa diikuti dengan Akta Pemberian Hak Tanggungan (APHT), yaitu terhadap perjanjian tersebut statusnya sah secara hukum, karena dalam Undang-Undang Nomor 4 Tahun 1996 tentang Hak Tanggungan tidak ada pengaturan yang membatalkan perjanjian kredit tersebut dibuat setelah memenuhi Pasal 1320 KUHPerdata.

2. Akibat hukum perjanjian kredit tanpa diikuti dengan Akta Pemberian Hak Tanggungan (APHT) menurut Undang-Undang Nomor 4 Tahun 1996 tentang Hak Tanggungan, akibat hukumnya yaitu :

a. Bagi bank

1. Bank dengan memberikan kredit tanpa diikuti Akta Pemberian Hak Tanggungan, maka status bank sebagai kreditur adalah kreditur konkuren, yang hak pelunasan hutangnya disamakan dengan hutang-hutang debitur yang preferen (didahulukan dari yang lain).

2. Bank tidak memiliki jaminan kebendaan terhadap kredit yang diberikan kepada debitur, diletakanlah asas umum hak seorang kreditur terhadap debiturnya, dalam mana ditentukan bahwa segala kebendaan debitur, baik yang bergerak maupun tidak bergerak, baik yang sudah ada maupun yang baru aka nada dikemudian hari, menjadi tanggungan untuk segala perikatan 
perseorangan, ini menunjukkan piutang kreditur meliputi seluruh harta debitur tanpa kecuali.

3. Bank pada dasarnya dalam memberikan kredit akan selalu mengharapkan jaminan dari debiturnya untuk menjamin pelunasan hutang-hutangnya.

b. Bagi debitur

1. Mendapatkan kemudahan yang diberikan oleh bank kepada debitur dalam hal percepatan proses pemberian kredit.

2. Sekalipun tidak diikuti Akta Pemberian Hak Tanggungan (APHT) dalam perjanjian kredit yang dibuat antara kreditur dan debitur, namun pelunasan hutang dari pada debitur terjadi wanprestasi yaitu mengacu pada Pasal 1131 KUHPerdata, dimana diletakkanlah asas umum hak seorang kreditur terhadap debiturnya, dalam mana ditentukan bahwa segala kebendaan debitur, baik yang bergerak maupun tidak bergerak, baik yang sudah ada maupun yang baru akan ada dikemudian hari, menjadi tanggungan untuk segala perikatan perseorangan, ini menunjukkan piutang kreditur meliputi seluruh harta debitur tanpa kecuali.

\section{F. Saran}

Dari semua permasalahan yang telah dibahas oleh penulis, maka kiranya penulis ingin memberikan beberapa saran yaitu :

1. Bank hendaknya dalam memberikan kredit kepada debitur tidak mengenyampingkan jaminan yang merupakan syarat yang mutlak dari suatu pemberian kredit, karena manfaat dari jaminan ini adalah sebagai alat pengamanan apabila usaha yang dibiayai dengan kredit tersebut gagal lain dimana debitur tidak mampu melunasi kreditnya dari hasil usaha yang normal, sehingga memberi hak dan kekuasaan kepada bank untuk mendapatkan pelunasan barang-barang jaminan tersebut serta hal ini dilakukan oleh instansi perbankan guna menghindari kredit macet, yang berdampak pada berkurangnya kinerja dan keuangan bank yang pada akhirnya dapat berujung pada tutupnya pada lukuiditasnya bank. Seharusnya dalam Undang-Undang Nomor 4 Tahun 1996 tentang Hak Tanggungan yang mewajibkan perjanjian kredit dengan Akta Pemberian Hak Tanggungan sebagai jaminan 
kreditur, dapat memasukkan sanksi terhadap perjanjian kredit jika dibuat tanpa Akta Pemberian Hak Tanggungan.

2. Bank hendaknya dalam perjanjian kredit khususnya untuk plafon di bawah 50 juta minimal harus diikuti dengan Surat Kuasa Membebankan Hak Tanggungan atau bisa dengan Akta Pemberian Hak Tanggungan dihadapan Pejabat Pembuatan Akta Tanah (PPAT), menurut Undang-Undang Nomor 4 Tahun 1996 tentang Hak Tanggungan, maka status bank sebagai kredit adalah kreditur preferen, yang hak pelunasan hutangnya diutamakan dengan hutang-hutang debitur lainnya, sehingga bank kepastian pelunasan hutang debitur, jika terjadi wanprestasi oleh debitur dan bank juga dapat meminimalkan resiko kerugian atas kegagalan kredit yang diberikan kepada debitur.

\section{DAFTAR PUSTAKA}

\section{G. Buku}

H. Budi Untung, Kredit Perbankan Di Indonesia, Andi Untung, Cet. I, Yogyakarta, 1959.

H. Salim, Perkembangan Hukum Jaminan di Indonesia, PT. Raja Grafindo Persada, Cet. I, Jakarta, 2004.

Irma Devita Purnamasari, Hukum Jaminan Perbankan, Kaifa PT. Mizan Pustaka, Cet. I, Bandung, 2011.

M. Bahsan, Hukum Jaminan Kredit Perbankan, PT. Raja, Cet. Grafindo Persada, Jakarta.

Mariam Darus Badrulzaman, Perjanjian Kredit Bank, Alumni, Cet. 1, Bandung, 1989.

Mukti Fajar dan Yulianto Achmad, Dualisme Penelitian Hukum Normatif dan Empiris, Pustaka Pelajar, Cet. I, Yogyakarta, 2010.

Soerjono dan H. Abdurrahman, Metode Penelitian Hukum, PT. Rineka Cipta, Cet. I, Jakarta, 2003.

Subekti, Hukum Perjanjian Kredit, PT. Intermasa, Cet. I, Jakarta, 1991.

Tan Thong Kie, Studi Notaris, Serba-serbi Notaris, PT. Ichtiar Baru Van Hoeve, Cet. I, Jakarta, 1994. 